\title{
PENERAPAN METODE KARYA WISATA PADA PEMBELAJARAN SEJARAH KELAS X IPS DI SMA NEGERI 1 SERUYAN MELALUI MODEL PEMBELAJARAN INKUIRI
}

\author{
Meli Hadijah \\ Progam Studi Pendidikan Sejarah FKIP Universitas Lambung Mangkurat \\ Banjarmasin \\ Email : melikhadijah123@gmail.com
}

\begin{abstract}
Abstrak : metode karya wisata dalam pembelajaran sejarah merupakan hal yang sangat sedikit atau sebagian dari sekolah jarang melakukan. Dikarnakan metode karya wisata tersebut merupakan pendidikan nonakdemis, sehingga tidak dapat menguatkan untuk dilakukan. Dalam hal ini metode karya wisata sebenarnya adalah tidakan yang sangat baik terhadap peserta didik. yang dimana guru membawa peserta didik kesuatu tempat yang bertujuan untuk melakukan pemebalajaran secara langsung, yang dimana dalam hal itu pemebelajaran didapatkan diluar kelas. Sehingga pserta tidak terlalu bosan untuk belajar yang hanya di dalam kelas. Akan tetapi tindakan tersebut agarmenarik sebuah pembelajaran sejarah, yang tidak hanya dilingkup dikelas saja, Akan tempat bisa belajar diluar kelas, dan mendapat informasi secara langsung tanpa dari guru.
\end{abstract}

Metode Karya wisata tersebut dapat melalui model pembelajaran Inkuiri yang merupakan peroses peserta didik menempuh memecahkan suatu masalah, merencanakan suatu eksperimen dan menganalisis data. Denagn adaya model tersebut mebangun sebuah karater pseerta didik dalam bertidak disiplin, jujur, dan betanggung jawab. Sehingga peserta didik mampun berpikir keritis dan bersikap seperti para ilmuan sains.

Kata kunci : metode karya wisata, pembelajaran sejarah, dan model pemebalajarn inkuiri.

\section{PENDAHULUAN}

Sitem pengajaran yang baik seharusnya dapat membatu mencapai tujuan-tujuan yang ingin dicapai dalam belajar. Meskipun peroses mengajar tidak dapat sepenuhnya bepusat pada pserta didik seperti pendidikan terbuka, tetapi yang perlu dicermati adalah bahwa pada hakekatnya peserta didiklah yang harus be;ajar dan mgembangkan diri atau karakter dalam diri peserta didik. dengan demikian perises balajar 
mengajar perlu berorientasi pada kebutuhan dan kemampuan siswa. Kegiatan-kegiatan yang dilakukan dalam peroses mengajar harus dapat memberikan penaglaman belajar yang berguna, bermanfaat dan menyenakan bagi peserta didik. Pengajaran tersebut perlu melakukan situasi atau suasana baru, dan menyajikan materi yang sesuai dengan kemampuan peserta didik.

Mengajar merupakan suatu aktivitas profesional yang memerlukan keterampilan tingkat tinggi dan mencangkup hal-hal yang berterkaitan dengan pengambilan keputusan-keputusan (Wisnata Putera, 1992 : 86 ). Pengajaran sekarang lebih dituntut lebih berfungsi sebagai peroses belajar mengajar dalam tindakan merecanakan, mengatur dan mengarahkan.

Tindakan tersebut dapat dilakukan dalam peroses belajar yang berupa metode karya wisata yang dimana karya wisata merupakan kegiatan perjalanan atau kunjungan kesuatu tempat dari kelompok yang berupa keluar dari sekolah atau raung kelas. Tujuan dari perjalanan tersebut melakuakn pengamatan dan mendapat informasi secara langsung yang ditemukan. Dalam hal ini mampu mebuat peserta didik memilki pengalaman yang menarik dalam belajar.

\section{METODE KARYA WISATA}

Metode tersebut merupakan metode yang dimana untuk membawa siswa dalam berkegiatan untuk melakukan aktifitas sebuah penelitian terhadap sesuatu benda atau berupa peritiwa-peristiwa yang ada. Dalam hal ini mengaitkan dalam hasil sebuah pembelajara sejarah, yang tidak hanya saja di ruang lingkup kelas akan tetapi diluar kelas. Metode ini juga memperlihatka suatu objek yang begitu menarik untuk dilihat.

Karya wisata merupakan suatu tindakan persiar atau perjalanan yang dilakukan oleh peserta didik dalam pengalaman belajar, terutama dalam tindakan belajar yang secara langsung dan terjun kelapangan. Pembelajaran tersbut merupakan bagian dari itgral dari kurikulum sekolah dan hal ini juga agar memper minatkanj dalam belajar. Meskipun karya wisata memiliki banyak hal yang besifat nonakademis, tujuan umum pendidikan segera tercapai, terutama dalam hal mengembangkan wawasan pengalaman tentang di luar kelas.

Karya wisata bukan sekedar rekreasi, tetapi untuk belajar atau memperdalam pelajarannya dengan melihat kenyataannya. Karena itu dikatakan teknik karya wisata, ialah cara mengajar yang dilaksanakan dengan mengajak siswa ke suatu tempat atau obyek tertentu di luar sekolah untuk mempelajari atau menyelidiki sesuatu seperti meninjau pabrik sepatu, suatu bengkel mobil, toko serba ada, dan sebagainya. 
(Roestiyah (2001).

Menurut (Isjonik, dkk.(2007 : 153). Karya wisata merupakan cara mengajar yang dilaksanakan dengan mengajak peserta didik ke seatu tempat atau objek yang beruapa diluar sekolah seperti meninjau suatu wisata atau museum. Metode karya wisata itu sendiri sangat efektif dalam mengajar ke peserta didik yang dimana guru lebih mudah dalam menyampaikan pembelajaran yang sesuai, karena metode karya wista memberikan suatu pengalaman langsung terhadap peserta didik yang dimana memudahkan peserta didik dalam mendapat informasi dan lebih bermakna.

Metode field trip atau karya wisata merupakan suatu perjalanan atau pesiar yang dilakukan oleh peserta didik untuk memperoleh pengalaman belajar, terutama pengalaman langsung dan merupakan bagian integral dari kurikulum sekolah. Meskipun karya wisata memiliki banyak hal yang bersifat non akademis, tujuan umum pendidikan dapat segera dicapai, terutama berkaitan dengan pengembangan wawasan pengalaman tentang dunia luar. (Mulyasa (2005)).

Teknik karya wisata, yang merupakan cara mengajar yang dilaksanakan dengan mengajak siswa ke suatu tempat atau obyek tertentu di luar sekolah untuk mempelajari atau menyelidiki sesuatu seperti meninjau pegadaian. Banyak istilah yang dipergunakan pada metode karya wisata ini, seperti widya wisata, study tour, dan sebagainya. Karya wisata ada yang dalam waktu singkat, dan ada pula yang dalam waktu beberapa hari atau waktu panjang. (Djamarah (2002)).

Metode karya wisata merupan salah satu metode pembelajaran yang memberi kesempatan untuk peserta didik dalam mengembangkan sebuah informasi dalam belajar. Karya wisata ini sendiri suatu cara dalam belajar yang mengajak peserta didik untuk keluar kelas atau memberikan suatu pengalaman yang menarik kesuatu tempat seprti museum atau tempat wisata yang dimana dapat bermafaat dalam belajar.

Manfaat dari metode karya wisata adalah peserta didik secra langsung mendapat kan pembelajarannya dan adanya pengelihatan yang secara langsung sehingga dapat melihat adanya peristiwa yang terjadi dahulu kala, dan peninggalan yang ada. Sehingga dalam pemeblajaran secara langsung dapat lebih berkesan dan memiliki daya ingat yang sangat kuat.

\section{PEMBELAJARAN SEJARAH}

Pembelajaran sendiri merupakan suatu peroses kegiatan belajar mengajar yang juga berperan dalam menentukan keberhasilan belajar siswa. Dari proses pembelajaran itu akan terjadi sebuah kegiatan timbal 
balik antara guru dengan siswa untuk menuju tujuan yang lebih baik. Untuk melakukan sebuah proses pembelajaran, terlebih dahulu harus dipahami pengertian dari kata pembelajaran.

Pembelajaran sejarah adalah peroses dimana seseorang atau sekelompok yang melakuakn sebuah aktivitas belajar-mengajar, didalamnya memuat pelajaran tentang kehidupan manusia di masa lampau dalam bentuk peristiwa, dilakukan dengan cara komunikasi dua arah sehungga pesan/nilai sebuah peristiwa tersebut dapat disampai dalam pembalajaran. ( Heri Susanto, 2019:28).

Menurut I Gede Widja (1989:23) pembelajaran sejarah adalah aktivitas belajar mengajar, didalamnya memuat pelajaran tentang peristiwa masa lampau yang berkaitan erat dengan masa kini, sebab dengan kacamata masa kini kita mampu mempelajari masa lampau. I Gede Widja juga berpendapat bahwa membelajarkan sejarah tidak semata hanya terkait fakta-takta dalam ilmu sejarah namun juga memerhatikan tujuan dari pendidikan pada umumnya, yaitu untuk mencapai kompetensi yang terdiri atas kognitif, afektif, dan psikomotorik. Pembelajaran sejarah diharapkan dapat membangun kesadaran, pengetahuan, wawasan, dan nilai berkenaan dengan lingkungan tempat diri dan bangsanya hidup.

Tujuan pembelajaran sejarah menurut Kasmadi (1996:13) adalah untuk menanamkan semangat kebangsaan, cinta tanah air, bangsa dan negara. Materi dalam pembelajaran sejarah ini mampu untuk mengembangkan potensi peserta didik untuk lebih mengenal nilai-nilai bangsa yang diperjuangkan pada masa lampau, dipertahankan, dan disesuaikan untuk masa yang kini dan dikembangkan dimasa yang akan datang, juga dalam sejarah dipaparkan mengenai berbagai peristiwa dan kejadian yang nyata yang telah terjadi dimasa lampau, bukan hanya karangan fiktif belaka, seperti kegigihan para pejuang melawan penjajah dalam mempertahankan harga diri bangsa.

Dapat disimpulkan pembelajaran sejarah merupakan suatu peroses pembelajran yang membangun suatu rasa kesadaran terhadap pentingnya waktu dan peristiwa yang telah terjadi, merupakan sbuah peroses yang dimana terjadinya dari masa lampau, hingga masa sekarang, dan masa depan sehingga dapat menyadarkan bhwa peserta didik memiliki rasa cinta tanah air dan bangsa

Dalam hal ini adanya konsep sejarah merupakan sebuah ilmu yang tantangan atau misi yang sanagt besar untuk memperbaiki peradaban umat manusia, sejarah banyak meberika pelajaran tentang konsep-konsep penting dalam mengahadpi kehidupan yang akan datang. Sejarah juga mengajarkan kita bagaimana memahami manusia dalam konteks masa 
lalu untuk membuat sejumlah keputusan dimasa yang akan datang. Hal tersebut tidak lah hanya sesederhana hanya nama, peristiwa, waktu dan tempat kejadian. Akan tetapi sejarah mampu menyadarkan individu dan masyarakat agar mampu menjadi warga ynag baik (Heri Susanto 2004:8).

\section{MODEL PEMBELAJARAN INKUIRI}

Inquiry adalah kata yang memilki banyak hal yang berupa perbedaan dalam konteks. Dalam bidang sains, dalam inquiry sendiri merupakan seni atau ilmu bertaya tentang alam dan menemukan jawaban atas pertayaan tersebut. inquiry dilakukan dengan langkah langkah, seperti observasi, dan pengukuran, hipotesis, interpretasi, dan penyusunan teori. Inquirymemerlukan eksperimentasi, refleksi, dan pengenalan terhadap kekuatan dan kelemahan metode yang digunakan. (Hebrank, 2000).

Menurut (Sund dan Trowbridge, 1973), model inkuiri merupakan sebagai pembelajaran yang mempersiap situasi bagi anak untuk melakukan eksperimen sendiri, dalam artian yang luas ingin melihat apa yang terjadi, melakuan sesuatu, mengunakan simbol-simbol dan ingin menjawab semua pertayaan yang tejadi pada dunia,_menghubungkan penemuan yang satu dengan penemuan yang lain, membandingkan apa yang ditemukan dengan yang telah dibuat para ilmuan.

Hamalik (2001:63) mengemukakan bahwa dalam pemebelajaran inkuiri atau (inkuiri based teaching) adalah salah satu starategi yang berpusat pada peserta didik yang dimana kelompok-kelompok peserta didik dibawa ke dalam suatu persoalan atau permasalahan yang mencari jawaban terhadap pertayaan-pertayaan di dalam suatu perosedur dan struktur kelompok yang diharuskan secara jelas. Strategi pembelajaran inkuiri sendiri menekankan kepada peroses mencari dan menemukan. Materi pembelajaran tidak diberikan secara langsung. Peran peserta didik tersebut pun dalam strategi ini bisa disebut dengan mencari dan menemukan sendri materi pelajaran, sedang guru berperan sebagai fasilitator dan pembimbing peserta didik untuk belajar.

Meneurut (Trowbridge, 1990), menyatakan bahwa model inkuiri adalah sebuah model proses pengajaran yang berdasarkan atas teori belajar dan perilaku. Inkuiri merupakan suatu cara menajar murid-murid bagaimana belajar menggunakan keterampilan,proses, sikap dan berpikir rasional. (Bruce 1992). Pendapat Bruce tersebut sependapat dengan, Cleaf (1991) menyatakan bahwa inkuiri adalah salah satu strategi yang digunakan dalam kelas yang beriorentasi proses.

Menurut Trowbridge (1990) menjelaskan model inkuiri sebagai peroses mendefinisikan dan menyelidiki masalah-masalah, merumuskan 
hipotesis, merancang eksperimen, menemukan data, dan menggambarkan kesimpulan masalah-masalh tersebut. esensi dari penagajaran inkuiri adalah menata lingkungan /suasana belajar yang berfokus pada siswa dengan memberikan bimbingan secukupnya dalam menemukan konsep konsep dan prinsip-prinsip ilmiah.

dari pendapat diatas dapat disimpulkan bahwa inkuiri adalah suatu peroses yang diraih oleh peserta didik dalam memecahkan masalah, menemukan data, merencanakan ekperimen, melakukan ekperimen, mengumpulkan dan menarik kesimpulan yang dilakukan. Model inkuari tersebut iyalah peserta didik terlibat secara mental maupun fisik untuk memecahkan suatu permasalahan yang diberikan guru. Dalam hal ini pun peserta didik untuk melakukan pemikiran yang begitu ahli dalam penelitian. Hal ini agar peserta didik da[at tercapai dalam hal yang bersikap seperti ilmuan sains, yaitu teliti, tekun, objek, jujur dan kreatif dalam memecahkan suatu masalah dan menghormati pendapat orang lain.

Tujuan model inkuiri tersbut yaitu membantu peserta didikm dalam berperilaku yang jujur, bersikpa disimplin, mengembangkan sikap intelektual dan keterampilan dalam berpikir dengan memberikan pertayaan dan mendapatkan jawaban atas dasar apa yang ingin ketahui dan dalam memecahkan masalah. 


\section{PENUTUP}

Dalam hasil dari atas tersebut dapat disimpulkan dalam metode karya wisata dapat membuka wawasan baru terhadap peserta didik didalam pembelajran dan mendapat pengalaman belajarn diluar kelas sehingga Membuat pserta didik mendapat materi secara langsung atau terjun kelapangan yang dilihat. Metode karya wisata ini pun mebuat peserta didik meneliti apa yang dilihat, mengamati semua aktifitas yang dilakukan, dan mendapatkan informasi secara langsung di lihat, Contohnya seperti dimuseum.

Tindakan tersebut pun berterkaikan dengan sebuah model inkuiri yang dimana modelm inkuiri tersebut merupakan model pembelajaran yang pengajiannya memberikan kesempatan terhadap peseta didik untuk menemukan informasi tanpa bantuan oleh guru melain mandiri dalam mencari informasi. Model inkuiri adalah rangkaian kegiatan pembelajaran yang menekankan pada proses perbipikir secara kritis dan analitis untuk mncari dan menemukan jawaban dari suatu masalah yang dipertayakan.

\section{DAFTAR PUSTAKA}

\section{A. Buku-Buku}

Hamalik, O. (1991). Strategi Belajar Mengajar. Bandung: CV Sinar Baru Isjonik, dkk. 2007. Pembelajaran Visioner Perpaduan Indonesia-Malaysia. Yogyakarta. Pustaka belajar 
Joyce, B. \& M. Weil. (1980). Models of Teaching. Boston-London: Allyn and Bacon.

Kasmadi, Hartono. (1996). Model-model dalam Pengajaran Sejarah. Semarang: Ikip Semarang Press.

Sund \& Trowbridge. (1973). Teaching Science by Inquiry in the Secondary School. Columbus: Charles E. Merill Publishing Company.

Susanto Heri. 2014. Seputar Pembelajaran Sejarah: Isu, Gagasan, dan Strategi dalam Pembelajaran. Yogyakarta : Aswaja Pressindo.

Susanto Heri \& Akmal, Helmi . 2019 . Media Pembelajaran Sejarah Era Teknologi Informasi ( konsep dasar, prinsip Aplikatif, dan Perancangannya). Banjarmasin : program studi Pendidikan Sejarah Fakultas Keguruan dan IImu Pendidikan Universitas Lambung Mangkurat.

Trowbridge, L.W. \& R.W. Bybee. (1990). Becoming a Secondary School Science Teacher. Melbourne: Merill Publishing Company

Widja, I Gede. (1989). Dasar-Dasar Pengembangan Strategi serta metode pengajaran Sejarah. Jakarta: Departemen Pendidikan dan Kebudayaan Direktorat Jenderal Pendidikan Tinggi Proyek Lembaga Pendidikan Tenaga Kependidikan.

Winata putera, US. 1992. Model-Model Pembelajaran. Jakarta. Depdikbud

B. Hasil Penelitian, Jurnal dan Makalah/ Prosiding

Kusmaryono. H \& Rokhis Setiawati. (2013). Penerapan Inquiry Based Lerning untuk mengetahui Respon Belajar Siswa Pada Materi Konsep dan Pengelolaan Koperasi. Jurnal Pendidikan Ekonomi Dinamika Pendidikan, Voll. VIII(02), 133- 145

Prawistasari, M. ( 2015) Metode Pembelajaran Hypnoteaching melalui Mind mapping Dalam Pembelajaran Sejarah (studi Pada Siswa kelas XI IPS SMA PGRI 6 Banjarmasin).

Suhada Hidayati. (2017). Model Pembelajran Inquiry dan Kemanpuan Berpikir Kritis Terhadap Terampilan Proses Sains Siswa Kelas V Pada Mata Pelajaran IPA. Jurnal Pendidikan Dasar vol. 8(02). 24 https/doi.org/10.21009/JPD.082.02

Susanto Heri.(2017). Pemahaman Sejarah daerah dan perinsip Terhadap keberadapan budaya dalam membina sikap nasionalisme. Jurnal sejarah dan Budaya. Tahuan sembil. No. 07

Widia Via, Dian Indihadi \& Rustono. (2016). Pengaruh Metode Karya Wisata Terhadap Hasil Belajar siswa Tentang Ekonomi Masyarakat Sekitar. 